\title{
Sociologie v Rakousku: spletitý příběh s dobrým koncem
}

\author{
Christian Fleck: Sociology in Austria \\ Basingstoke, Palgrave Macmillan 2016, vii + 97 s.
}

Ne vždy je geografická blízkost zárukou vzájemné obeznámenosti a spolupráce. Rakouská a česká sociologie jsou nepropojené a jedna druhou ignorující národní vědecké komunity. Znalosti o české sociologii v Rakousku jsou v nejlepším případě velmi malé a v zásadě stejně nízké je povědomí o rakouské sociologii v České republice. Vliv rakouské sociologie naprosto nelze srovnávat s vlivem, který na domácí sociologii měla rovněž sousední sociologie polská, nebo dokonce sociologie globálně vlivných akademických mocností jako Francie a Spojené státy či z opačné zeměpisné i mocensko-politické strany Rusko. Přitom se na jih od Dyje dělo a stále děje leccos zajímavého a vzhledem k mnoha kulturním i strukturálním podobnostem mezi oběma zeměmi by stálo za to vývoj v rakouské sociologii sledovat pozorněji.

Za nedostatečnou vzájemnou znalost zřejmě zčásti může jazyková bariéra, němčina není dnes již ani zdaleka tak rozšířená jako angličtina a jako bývala kdysi. Literatury o rakouské sociologii samozřejmě existuje dost, ale převážně $\mathrm{v}$ němčině ( $\mathrm{k}$ výjimkám typicky patři kapitoly vydané $\mathrm{v}$ rưzných přehledových sbornících o evropské nebo světové sociologii [např. Fleck, Nowotny 1993]). Proto je dobře, že loni vyšla anglicky psaná knížka Sociologie v Rakousku od Christiana Flecka. I když se jedná o knihu stručnou a psanou bez ambice říci jednou provždy vše podstatné, může posloužit k prvnímu seznámení se se sociologií u našich jižních sousedů a případně i jako podklad k zamyšlení nad starším i zcela nedávným vývojem české sociologie.

V následujícím textu jsem se snažil držet v mezích žánru recenze, ale psal jsem jej s trochu jiným záměrem, než jaký u recenzí bývá obvyklý. Vzhledem ke svým omezeným znalostem rakouské sociologie se nezabývám poznávacím přínosem této knihy ani jejím místem v dosavadní literatuře. Ono ostatně jde do značné míry o knihu "na export", která shrnuje dějiny rakouské sociologie do několika zhuštěných krátkých kapitol psaných tak, aby si zahraniční čtenáři mohli o tématu udělat první představu. Zaměřuji se spíše na podobnosti a rozdílnosti trajektorie rakouské sociologie ve srovnání s dráhou, kterou ve stejné době urazila česká sociologie. V této souvislosti se přímo vnucují klasické komparativní, nebo dokonce kontrafaktuální otázky: čím vysvětlit odlišné výsledky, když mnohé výchozí podmínky byly stejné? Vyvíjela by se česká sociologie určitého období podobně jako sociologie u sousedů, kdyby nedošlo k některým zlomovým událostem, které vývoj u nás posunuly jiným směrem? 


\section{Neznámí sousedé}

České čtenáře může po přečtení Sociologie v Rakousku napadnout, že navzdory zeměpisné blízkosti a nadlouho společným politickým dějinám má česká sociologie s tou rakouskou společného velmi málo. Nějaké sdílené body by se při troše dobré vưle našly, ale jsou vzácné a nevýznamné. Tím asi nejzajímavějším dosud zůstává role mladistvého Tomáše G. Masaryka (jehož Fleck nezmiňuje) jako jednoho z prvních učitelů proslovujících na Vídeňské univerzitě v letech 1879-1882 přednášky na aspoň částečně sociologická témata. Mnohem viditelnější než tato a další podobné epizody je však skutečně překvapivá absence vzájemné znalosti a ovlivnění, nedostatečné kontakty a velmi omezená míra spolupráce.

Pokud by se někdo odvážil položit otázku, který rakouský sociolog výrazně ovlivnil českou sociologii, patrně by zavládlo zdvořilé mlčení. Př́ipadně by odpověd narazila na námitku, že sice dotyční z Rakouska pocházejí, ale kariéru udělali a známými se stali v zahraničí: Paul F. Lazarsfeld nepochybně českou sociologii ovlivnil, ale jako ",americký“ sociolog a ředitel newyorského Bureau of Applied Social Research [k Lazarsfeldovu přínosu viz zejména Jeřábek 2014]. Podobně si možná ne každý spojuje s Rakouskem uznávanou socioložku vědy Karin Knorr-Cetina, která působí především na univerzitách v Německu a USA. Mezi "skutečně rakouskými“" akademiky jsou takoví, kteří na české prostředí mají určitý vliv - např́íklad filosof "společnosti nevzdělanosti“ Konrad Paul Liessmann nebo sociolingvistka Ruth Wodak - nikdo z nich však není sociolog sensu stricto.

Většímu vlivu rakouské sociologie na českou sociologii nebo naopak v minulosti nenapomohla ani migrace jedním nebo druhým směrem. Mnohdy totiž zůstalo jen u biografických souvislostí, které už vzhledem k dalšímu vývoji životní dráhy dotyčných osob nevyústily ve zprostředkovávání mezi českým a rakouským intelektuálním prostředím. Výjimku, i když z hlediska sociologie jen okrajovou, představuje například známý sociálnědemokratický marxistický teoretik Karel Kautský, který se narodil v Praze do smíšené česko-německé rodiny. I když pozdější „,renegát“ Kautský se v devíti letech s rodinou odstěhoval do Vídně a celý dlouhý život prožil převážně v Rakousku a Německu, styky s českým prostředím stále udržoval.

Za první Československé republiky se samozřejmě o sociologii v Rakousku něco vědělo a např́íklad o průkopnickém výzkumu nezaměstnanosti provedeném v Marienthalu (viz níže) se psalo v tehdejších sociologických časopisech krátce poté, co byly zveřejněny jeho výsledky [Hoffmann 1934]. Silnější kontakty však existovaly obvykle jen mezi rakouskými a českými Němci nebo německojazyčnými Židy. Po nástupu nacismu v Německu a autoritativního režimu v Rakousku se československý stát stal demokratickým útočištěm pro politicky pronásledované osoby a př́padů rakouské "mobility“ do Československa lze najít celou řadu. Do Prahy, svého rodného města, se vrátil právní teoretik Hans Kelsen, byl však záhy vyštván německými nacionály a nacionálními socialisty [Míšková 2002: 26-28]. Vůdce rakouské sociální demokracie a autor několika sociolo- 
gických prací Otto Bauer zase strávil roky 1934-1938 v exilu v Brně. Na českou sociologii (snad s výjimkou sociologie práva) však tyto a další epizody neměly prakticky žádný dopad.

Stejně tak zůstala bez vlivu na rakouskou sociologii pozdější československá emigrace během komunistického období. Ta nebyla př́liiš rozsáhlá, a pokud zahrnovala známé osobnosti, měly k sociologii většinou vztah jen nepřímý. Právní filosof a logik Ota Weinberger opustil Československo v roce 1968 a v roce 1972 se stal profesorem ve Štýrském Hradci. Známý politik, právní teoretik a politolog Zdeněk Mlynář emigroval do Vídně v roce 1977, působil v několika rakouských výzkumných ústavech a v roce 1989 se stal profesorem politologie v Innsbrucku. Mlynářova manželka Irena Dubská, první šéfredaktora Sociologického časopisu v 60. letech, v rakouském exilu v akademické dráze nepokračovala. Nikdo z nich nesehrál roli výraznějšího prostředníka mezi českým a rakouským sociologickým světem.

V nových poměrech po roce 1989 se mohlo zprvu zdát, že pro spolupráci mezi českými a rakouskými sociology nastaly lepší časy. Čeští sociologové se zúčastnili první konference Evropské sociologické asociace, která se z iniciativy rakouských sociologů konala v roce 1992 ve Vídni, jezdilo se dokonce i na kongresy Rakouské sociologické společnosti [Illner, Machonin 1992; Jeřábek 1993]. Vznikaly mezinárodní výzkumné projekty sponzorované rakouskými institucemi, které se zabývaly tehdy významnými transformačními tématy, např́klad projekt „Sociální náklady ekonomické transformace ve střední Evropě" (SOCO), financovaný vídeňským Ústavem pro vědy o člověku (IWM), rakouskou vládou a Fordovou nadací [např. Večerník 1993]. Po opadnutí prvního nadšení z transformace následovala ještě druhá vlna už výrazně menšího nadšení $\mathrm{z}$ „Východního rozšîření" Evropské unie v roce 2004, kterou rovněž provázely výzkumné projekty financované z Rakouska. Od té doby se však žádné další nadšení nedostavilo a tomu odpovídá i poměrně nízká úroveň spolupráce s rakouskými kolegy. Jistě probíhají různé projekty a spolupráce v rámci evropských programů, česko-rakouského fondu AKTION, programu CEEPUS a dalších programů, fungují akademické výměny ERASMUS, čeští autoři občas publikují v rakouských časopisech nebo naopak. O skutečně viditelné a něčím speciální spolupráci českých sociologů s rakouskými, odpovídající společné minulosti a blízkosti, však nemůže být řeč.

Tato stručná a neúplná rekapitulace vzájemného (ne)zájmu potvrzuje onen první dojem, podle něhož Fleck pojednává o národní sociologii, která je nám vlastně dost vzdálená. Přesto je v jeho knize možné najít celou řadu tvrzení, která přímo vybízejí $\mathrm{k}$ tomu, aby byla vztažena $\mathrm{k}$ české sociologii. Některé výchozí podmínky jsou totiž pro českou a rakouskou sociologii společné a ony rozdílné výsledky, ke kterým se v každé zemi došlo, nabádají k zamyšlení. Takovými sdílenými podmínkami jsou: podobná politická polarizace společnosti (silný konflikt mezi konzervativní katolickou tradicí a socialistickými proudy); společný institucionální rámec akademického života existující do roku 1918 a v řadě ohledů přežívající mnohem déle; realita středně velkého (v Evropě) či spíše malého 
(ve světovém srovnání) státu a tomu odpovídající pravidla hry v akademickém prostředí, odlišná od toho, jak disciplína finguje ve velkých zemích. A samozřejmě obě národní tradice mají společnou také zkušenost hluboké diskontinuity, nebo jak ř́́ká Fleck „deinstitucionalizace“ [Fleck 2016: 10]. . Ta sice české země postihla vícekrát než Rakousko, zato v Rakousku byl podle všeho úpadek způsobený nacismem ještě hlubší než kterýkoli ze tř́i pádů sociologie v Československu.

\section{Předválečný rakouský „zázrak“ a jeho konec}

Christian Fleck z univerzity ve Štýrském Hradci je jedním z nejvýznamnějších dnešních historiků sociologie $\mathrm{v}$ Rakousku a v dalších německojazyčných zemích. Různými stránkami vývoje rakouské sociologie se zabýval už mnohokrát. V útlé knize Sociologie v Rakousku nepodal co nejvíce neutrální, nehodnotící a popisný přehled naplněný daty, institucemi a jmény, ale spíše jasně vypointovaný příběh zaměřený na hlavní charakteristické rysy, přednosti a zejména slabiny rakouské sociologie. Jeho výklad sahá od počátkư oboru v Rakousku až po první dekádu současného století, chybí však vylíčení situace a hlavních proměn v posledních 10 letech.

Z důvodů, jejichž objasnění leží za obzorem této recenze, Rakousku nikdy nechyběli intelektuálové, kteří jeho společenské a politické pořádky rádi vystavovali sžíravému posměchu. Za všechny je třeba zmínit Roberta Musila, Thomase Bernharda nebo Elfriede Jelinek. Fleckova kniha se vyzněním některých partií těmto literátům docela blíží. Kritikou a sarkasmem rozhodně nešetří. $\mathrm{V}$ tomto ohledu je zjevně určena nejen zahraničnímu, ale především domácímu, rakouskému publiku. Jak už ovšem bylo řečeno, nás zajímá především to, co z Fleckova výkladu může rezonovat s našimi znalostmi o české sociologii.

Hlavním, nápadně "musilovským“ motivem Fleckovy knihy je zaostalost, opožděnost a jiné formy nedostatečnosti rakouské sociologie: „následující stránky popisují příběh slepých uliček, selhání, podvodů, neoprávněného přivlastňování si a nekompetence bez jiného štastného konce, než je ten, který by se dal nazvat ,dosažením banality “" [s. 5]. Přitom však začátky rakouské sociologie byly mimořádné a řada jejích představitelů před druhou světovou válkou dosáhla světového ohlasu. Př́činu, proč je s malým Rakouskem spojováno tolik významných jmen, je jistě třeba hledat v situaci do roku 1918, kdy rakouské země a především Vídeň byly centrem říše, která měla jen v předlitavské části skoro 30 milionů obyvatel. Centrum přitahovalo talenty a ambice z území celého státu i ze zahraničí. Př́značný pro rakouskou sociologii oné doby byl podle Fleckova výkladu jednak malý výskyt „„̌̌istých“ sociologů a naopak značný počet osobností, které do sociologie zasáhly třebas i významně, ale pouze částí svého díla (například svérázný

${ }^{1}$ Dále jsou odkazy na recenzovanou knihu uváděny pouze číslem stránky $\mathrm{v}$ hranaté závorce. 
sociální teoretik a zároveň polní podmaršál Gustav Ratzenhofer, politik, první prezident Rakouska po druhé světové válce a příležitostný právní sociolog Karl Renner nebo světoznámý ekonom Joseph A. Schumpeter). Jednak byl pro rakouskou situaci typický velký počet sociologů židovského původu [s. 16], což souviselo s národnostním složením obyvatelstva, vzdělanostním a sociálním vzestupem části židovské populace a ovšem také s přetrvávajícími protižidovskými restrikcemi. Do této kategorie patřilo několik výrazných představitelů oboru, jako třeba právní sociologové Eugen Ehrlich, profesor na univerzitě v Černovicích v Bukovině, nebo krakovský rodák, profesor na univerzitě ve Štýrském Hradci Ludwig Gumplowicz, na kterého si dělá oprávněné nároky také polská sociologie [Szacki 1995: 15-19]. S ohledem na sílící antisemitismus v průběhu dvacátých a zejména třicátých let je třeba připomenout, že židovského pưvodu byli také již zmiňovaní Kelsen a Bauer, někteří další austromarxisté nebo Paul F. Lazarsfeld a jeho spolupracovníci.

Je pozoruhodné, že rakouská sociologie vydala své nejpůvodnější plody ve dvou desetiletích po roce 1918, kdy se z Rakouska stala země s těžkými ekonomickými problémy a neúměrně velkým státním i univerzitním aparátem. Akademická místa nevznikala a nebyla dostupná téměř pro nikoho jiného než pro rakouské nacionály; pro socialisty, Židy i mnohé liberály bylo téměř nemožné se habilitovat a nastoupit univerzitní dráhu [s. 19]. Právě z těchto skupin však vzešli světově nejúspěšnější rakouští sociální vědci. Ekonomická a sociální opora jejich činnosti přitom byla pravým opakem státem placeného zaopatření pro akademické pracovníky, které se začalo rozvíjet až po druhé světové válce. Živili se v soukromém sektoru jako právníci, manažeři nebo novináři, zastávali špatně placené učitelské posty, pracovali pro odbory nebo politické strany. Scházeli se nejen v univerzitních posluchárnách, ale častěji v kancelárích, bytech nebo v kavárnách. Přesto, nebo možná právě proto vytvořili řadu děl trvalejší hodnoty. Jeden z nich, Friedrich August von Hayek, se domníval, že právě nedostupnost placených akademických míst (což tehdy byly skoro výhradně profesury) nutila rakouské sociální vědce získávat velmi široké praktické zkušenosti, a to jejich myšlení osvobodilo od př́lišné spekulativnosti [Hayek 1992: 24-25].

Př́kladů fungování tohoto modelu existuje celá řada. Uplatňoval se i v Praze, známý je případ úředníka Dělnické úrazové pojištoovny pro Království české Franze K. O finančním právníku a bankovním manažerovi Alfredu Schützovi údajně Edmund Husserl jednou prohlásil, že to je "mladý muž z Vídně, který ve dne pracuje v bance a v noci je fenomenologem" [Barber 2004: 81]. Okruh Schützových pracovních úkolů byl opravdu široký: vedle vedení velkého oddělení v bance a vyřizování složité bankovní agendy byl členem správních rad řady společností nebo např. organizoval akvizice pro pivovarnické společnosti jako Heineken. Současně však ve volném čase navštěvoval soukromé semináře pořádané neoliberálním ekonomem Ludwigem von Misesem, který sice přednášel na univerzitě jako mimořádný profesor, ale živilo jej zaměstnání v obchodní a živnostenské komoře. Jiným podobným př́ípadem byl Felix Kaufmann, který 
publikoval zejména v oblasti metodologie sociálních věd, ale živil se jako manažer ropné společnosti. Více nalevo se spolupracovalo se sociální demokracií, která ve dvacátých letech vládla v hlavním městě („rudá Vídeň“). Ekonom a sociolog Otto Neurath přispěl k rozvoji metodologie sociálních věd jako člen vídeňského kruhu logických pozitivistů, vedle toho založil sociální a hospodářské muzeum na vídeňské radnici a pro zpř́stupnění kvantitativních údajů širší veřejnosti vyvinul dodnes běžně používanou zobrazovací metodu izotypů [s. 17]. Patrně největší dopad na pozdější dějiny světové sociologie měl mezi aktivitami rakouských sociologů třicátých let výzkum Paula Lazarsfelda, Marie Jahoda, Hanse Zeisela a jejich spolupracovníků v obci Marienthal týkající se sociálně-psychologických důsledků dlouhodobé nezaměstnanosti [Fleck 1990: 159-178; Jeřábek 2014: kap. 8]. Nikdo z hlavních autorů této studie neměl zajištěný „plný úvazek“ v akademické sféře, pouze Lazarsfeld byl částečně zaměstnán na Vídeňské univerzitě jako asistent $\mathrm{v}$ Ústavu psychologie manželů Bühlerových. Jinak se živili jako zakázkoví výzkumníci v Lazarsfeldem vedeném Výzkumném středisku pro hospodářskou psychologii, jako učitelé na gymnáziu nebo v dělnických kurzech a jako novináři [s. 19-20].

Jen na okraj se Fleck zmiňuje o konzervativní části sociologického spektra, která v Rakousku v meziválečném období byla velmi silná. Po celou dobu rakouské první republiky byl ve Vídni profesorem národního hospodářství a společenské teorie Othmar Spann (habilitován 1907 na německé technice v Brně), ultrakonzervativní teoretik stavovského státu, který dlouho, i když nakonec neúspěšně usiloval o roli učitele německých nacistů [s. 25]. Jedná se o nanejvýš problematickou kapitolu dějin rakouské (a dlužno říci také německé a sudetoněmecké) sociologie, možná by však právě proto měla být zahraničním čtenářům představena důkladněji. ${ }^{2}$

Vzhledem $\mathrm{k}$ tomu, že české země dlouho byly součástí rakouského státu, nabízí se otázka, co bylo „u nás“ před druhou světovou válkou jinak a proč? Co do akademického pěstování oboru byla česká sociologie díky Masarykově pưsobení na české univerzitě v Praze po dlouhou dobu s rakouskou na srovnatelné úrovni a po roce 1918 ji v oblasti institucionalizace dokonce výrazně předběhla. V Československu vzniklo několik profesur sociologie, sociologická společnost byla založena $\mathrm{v}$ roce 1925, v letech 1930 a 1931 vznikly dva specializované sociologické časopisy. V předválečném Rakousku nic z toho neexistovalo (viz srovnávací studii rané institucionalizace sociologie ve středoevropských zemích Janák [2014]). V oblasti intelektuálního vlivu ve světě však byla mnohem úspěšnější rakouská sociologie. Vysvětlení je zřejmě třeba hledat $\mathrm{v}$ současném působení několika faktorů: $v$ českém prostředí sociologie nepřitahovala nejnadanější jedince, ti spíše volili tradičnější obory jako historii, filosofii nebo lingvistiku. Naopak v Rakousku prvních desetiletí minulého století sociální vědy přilákaly řadu prvotříd${ }^{2}$ Je třeba dodat, že autor knihy toto téma včetně postavy Othmara Spanna důkladně zpra-
coval v řadě německých publikací jako např. Fleck [1988]. 
ních mozků; prostředí imperiální a postimperiální Vídně bylo více kosmopolitní a otevřenější vnějším intelektuálním vlivưm, tamější intelektuálové zřejmě také disponovali mezinárodním sociálním kapitálem ve větší míře než jejich kolegové v Praze nebo Brně; nepochybně stimulující roli sehrávala jazyková a kulturní blízkost k Německu; větší soukromé bohatství a lepší příležitosti k výdělku v soukromé sféře umožňovaly některým $z$ úspěšných rakouských sociálních vědců fungovat podle modelu soukromých učenců; levice a Židé byli v Rakousku stále více vytlačováni z politického života, což znamenalo, že sociologové patřící k těmto kategoriím mohli energii, kterou nespotřebovávalo budování státu, věnovat vědeckým projektům.

\section{Dvacet let stagnace}

O prvních desetiletích vývoje rakouské sociologie po roce 1945 Fleck píše s jasným despektem. I když je opět na místě jej podezř́vat z určité jednostrannosti, je zřejmé, že rozdíl mezi Lazarsfeldem a kol. v roce 1933 a rakouskými profesory sociologie z padesátých let je velký.

Vstupní pasáž knihy vykresluje efektní protiklad: v lednu 1945 se v New Yorku scházejí Paul Lazarsfeld, Robert K. Merton a Charles W. Mills u luxusní večeře, jejímž výsledkem je nabídka zaměstnání pro Millse v Bureau. Ve stejné době jiný sociolog, Benedikt Kautsky, syn sociálnědemokratického teoretika Karla Kautského, spolu se stovkami dalších vězňů bojuje o holý život na pochodu smrti z koncentračního tábora Osvětim do tábora Glivice. Tyto epizody symbolizují dějinné události, jimiž bylo na dlouho rozhodnuto o tom, že Evropa ztratila svůj světový primát ve většině podstatných oblastí moderního života, včetně vysokého školství a výzkumu, a na její místo nastoupily Spojené státy [s. 2-5]. Rakousko se podle Flecka z otřesů druhé světové války a toho, co jí předcházelo, vzpamatovávalo déle než jiné evropské země a totéž platí pro rakouskou sociologii [s. 7-9].

Po konci války, kdy Rakousko bylo až do roku 1955 okupováno vítěznými mocnostmi, bylo vysoké školství a věda v rukou rakouských úřadů, to však k rozvoji akademického života nepřispělo právě pozitivně. Nejexponovanější bývalí nacisté byli propuštěni, řada z nich se však po pár letech na univerzity nenápadně vrátila. Hůře se vedlo profesorům z ",̌íše $e^{\prime \prime}$, kteří museli odejít bez možnosti návratu. Zároveň se však neuskutečnil ani návrat kompetentních akademiků z exilu, protože pro to nebyla domácí podpora [s. 8]. Rakouské univerzity podle Flecka ovládli nevýrazní konformisté, kteří stáli v cestě návratu místní vědy na světovou úroveň. Šlo převážně o osoby, které byly v roce 1938 ve středních patrech akademické hierarchie, přežily čistky po nástupu nacismu a v roce 1945 již byly profesory. Tento intelektuální úpadek vyvolaný postupnou likvidací různých skupin akademiků Fleck označuje jako „autochtonní provincializaci“ [s. 8, 26]. Prodlužování stagnace mnoho let po válce pak už ovšem mělo i jiné př́činy. 
Velkou roli v tom sehrál nový rakouský politický model, neokorporativismus, v němž se veškerá rozhodnutí dělala na základě kompromisu dvou hlavních politických stran, křestáanskodemokratických lidovců a sociálních demokratů, které zpravidla stavěly stranickou linii nad výkon. Částečně byla za trvající úpadek odpovědná také strnulá "teutónská“ organizace univerzit (termín Fleck přebírá od Johana Galtunga [Galtung 1981]), k níž se vrátíme níže.

První poválečné dvacetiletí $\mathrm{v}$ dějinách rakouské sociologie se vskutku nezdá být př́iliš zajímavé. Jména klíčových postav, katolicky orientovaných sociologů jako August Maria Knoll, od roku 1950 profesor sociologie na Vídeňské univerzitě, nebo Johann Mokre, ustavený už o rok dříve profesorem filosofie a dalších oborů včetně sociologie ve Štýrském Hradci, jsou dnes málo známá. Za zmínku stojí rozvoj empirických sociologických šetření pod patronací katolické církve, jehož součástí bylo založení vídeňského Ústavu pro církevní sociální výzkum (Institut für kirchliche Sozialforschung) v roce 1952 [s. 30], který podle veřejně přístupných údajů existoval až do roku 2000. Také do tohoto období, konkrétně do roku 1950, spadá založení Rakouské sociologické společnosti pod Knollovým předsednictvím, organizace však nevyvíjela skoro žádnou činnost a jejím smyslem zřejmě bylo - podobně jako při zakládání sociologických společností v některých komunistických zemích koncem padesátých let - umožnění účasti rakouských sociologů na konferencích Mezinárodní sociologické asociace [s. 27].

O něco známějšś než první pováleční profesoři sociologie byl Knollův pokračovatel ve Vídni Leopold Rosenmayr. Fleck tohoto důležitého poválečného zástupce empirické sociologie, průkopníka sociologie mládeže, rodiny a stárnutí v Rakousku, líčí jako odborně nepř́lišs výraznou a spíše manažersky (ba dokonce mocensky) orientovanou postavu, oportunistu a autoritáře [s. 38-40]. Zde by zřejmě opět mělo bliknout červené světlo a čtenář musí brát Fleckův výklad na toto téma s jistou rezervou. Protože se však Rosenmayr stal profesorem na vídeňském Ústavu sociologie už počátkem šedesátých let, zůstal jím do poloviny devadesátých let a byl aktivně činný až do své smrti v roce 2016, je v souladu s negativním hodnocením, které mu Fleck vystavuje, že se příslušná kapitolka knihy jmenuje „neštěstí sociologie“. V této věci není na vnějším pozorovateli, aby vynášel soudy, určitě je však Fleckovi možné dát zapravdu v obecnější otázce, když tvrdí, že ${ }_{\text {,V }}$ prostředí obydleném pouze hrstkou aktérů může mít osobnost jednoho jednotlivce obrovské důsledky“" [s. 39].

\section{Nový rozvoj od šedesátých let}

Poválečný vývoj rakouské sociologie zprvu měl pramálo společného $\mathrm{s}$ časově souběžnými proměnami sociologie v Československu. Odlišné bylo už samotné východisko v roce 1945: na československých univerzitách se odstraňovaly následky německé okupace, obnovovala se předválečná sociologie, ale zároveň se začala připravovat diktatura komunistické strany. V Rakousku se více nebo méně 
upřímně denacifikovalo a otřesené univerzity zprvu zaujaly obrannou pozici bez větších ambicí dostat se ve společenských vědách na mezinárodní úroveň. Institucionální náskok, který československá sociologie zvyšovala až do roku 1948, byl s likvidací oboru ztracen, ale v Rakousku, jak jsme viděli, se dohánělo jen pomalu. Když v roce 1964 podnikli Vladimír Čech a Pavel Machonin okružní cestu po rakouských sociologických institucích, mohli napsat ve zprávě, která je doposud asi jediným českým př́íspěvkem o rakouské sociologii v Sociologickém časopise, že sociologie u našich jižních sousedů „... prozatím představuje spíše okrajovou sféru evropské sociologie“ [Čech, Machonin 1966: 844]. V obou zemích rozvoj sociologie nabral nový dech v polovině šedesátých let. Zdroje tohoto obratu byly přitom dost podobné i navzdory rozdílnému politickému zřízení a patřily k obecnějšímu duchu doby, jenž ovládal Západ i Východ: určovaly jej zejména vědeckotechnický optimismus, expanze vzdělávání, snaha o vědecké řešení sociálních problémů [s. 45].

Na této fázi vývoje sociologie v Rakousku je pro českého pozorovatele zajímavé, že jeho hlavním tahounem nebyly jen univerzity, ale také - a ve výzkumu především - mimouniverzitní ústavy. Nově vzniklý mimouniverzitní výzkumný sektor tvořený velkým množstvím menších subjektů je zřejmě třeba chápat jako funkční ekvivalent československé/české akademie věd, samozřejmě při zachování povědomí o mnoha klíčových rozdílech.

U zrodu toho nejdůležitějšího mimouniverzitního výzkumného ústavu stál v roce 1959 Paul Lazarsfeld, který se jako vyslanec Fordovy nadace marně pokoušel v Rakousku vytvořit mezinárodní postgraduální školu pro empirický sociální výzkum. Lazarsfeld, který ve stejné době sbíral velmi pozitivní dojmy o talentovaných mladých sociálních vědcích $\mathrm{v}$ Polsku a Jugoslávii (bohužel však z důvodů, které dosud nejsou dostatečně známy, ne v Ceskoslovensku), byl z rakouských kolegů zoufalý: „žádné mozky, žádná iniciativa, žádná spolupráce“ (dopis P. Lazarsfelda řediteli Fordovy nadace Shepardu Stoneovi, 29. 6. 1959 [citováno podle s. 33-34]). Z velkoryse pojaté postgraduální školy ve Vídni nakonec vinou mezistranické žárlivosti a intrik představitelů různých institucí sešlo, Lazarsfeld místo ní nakonec pomohl založit centrum pokročilých studií v kalifornském Palo Alto. Vídeň však úplně zkrátka nepřišla. Lazarsfeld a další významný rakouský emigrant, ekonom a jeden z průkopníků teorie her Oskar Morgenstern prosadili v roce 1963 založení Ústavu vyšších studií (Institut für Höhere Studien, IHS), opět se štědrou podporou Fordovy nadace. I když dosazování ředitelů a zaměstnanců podle stranického klíče napáchalo v prvních letech existence institutu poměrně velké škody, nakonec se etabloval jako špičková mimouniverzitní vzdělávací a výzkumná instituce [s. 35-38, 40-41].

Význam „Fordova ústavu“ (tj. IHS) v prvních dekádách jeho existence se dá náležitě docenit z českého hlediska, protože u nás taková instituce citelně chyběla a dosud chybí. Institut poskytoval studentům a asistentům (v dnešním jazyce: postdoktorandům) vzdělání na nejpokročilejší (tzn. tehdy převážně americké) úrovni v jednom z trojice oborů: sociologii, ekonomii nebo politologii. Na pozi- 
cích hostujících profesorů zaměstnával známé americké a západoevropské vědce, jakými byli vedle zakladatelů institutu např. James Coleman nebo Aaron Cicourel. Studenti a postdoktorandi pocházeli téměř výhradně z Rakouska, což někteří zahraniční pozorovatelé považovali za vážný handicap. Podle Colemana byl ústav pokročilých studií zaměřený pouze na Rakousko zhruba totéž jako ústav pokročilých studií pro stát Tennessee [s. 40]. Avšak těm nejtalentovanějším absolventům umožňoval nastoupit vskutku mezinárodní vědeckou kariéru. Helga Nowotny, Karin Knorr-Cetina, Max Haller a někteří další nabízených možností využili. Jen sociologické instituty na rakouských univerzitách absolventy IHS př́liš ochotně nezaměstnávaly, prvním profesorem z jejich řad v Rakousku se stal až Haller v roce 1985 [s. 41].

\section{Univerzitní sociologie: slonovinová věž a její demokratizace}

Pro rakouskou sociologii jakožto univerzitní obor byl zlomovým rok 1966, kdy došlo $\mathrm{k}$ větší reformě univerzitního studia. Sociologie se poprvé stala samostatným studijním programem (totéž se ve stejné době odehrálo také v Československu) a okamžitě bylo otevřeno studium tohoto oboru ve Vídni a na nově založené univerzitě $\mathrm{v}$ Linci, $\mathrm{k}$ nimž se $\mathrm{v}$ dalších dekádách přidaly i další rakouské univerzity [s. 48]. S expanzí sociologie souviselo vytvoření nových profesur, ty však byly podle Flecka udělovány nepř́liš výrazným kandidátům, jež spojovala zejména blízkost ke katolické církvi - nebot v letech 1966-1970, kdy došlo k jejich instalaci, v zemi vládla jednobarevná vláda lidovcủ. Tato a další profesorská jmenování se podle autora stala odrazem „,sklonu ke klesající míře reputace“, který se uplatňuje tehdy, když průměrní akademici z obavy před konkurencí jmenují jako své kolegy a nástupce jedince ještě slabší, než jsou oni sami [s. 49]. Opět při neznalosti osob a reálií nemohu posoudit, zda je Fleckovo hodnocení možné akceptovat, ale je faktem, že mezi novými profesory z konce šedesátých let není žádná mezinárodně známá osobnost. Onen "sklon ke klesající míře reputace“ však rozhodně není jen rakouským neduhem.

Problémy rakouských univerzit se samozřejmě neomezovaly jen na politické ingerence na konci šedesátých let, ale pokračovaly i nadále. Strukturálním nedostatkem univerzit dlouho byla feudální moc profesorů založená na systému profesorských stolic, který se liší od systému kateder, jaký známe u nás. Profesor mohl podle libosti obsazovat jemu přidělená asistentská místa, zpravidla dvě, rozhodoval o udělení smlouvy svým podřízeným na dobu neurčitou a měl hlavní slovo při habilitaci svých asistentů [s. 67]. V typickém prrípadě se postupem doby kolem každého profesora usadilo několik soukromých docentů zaměstnaných na dobu neurčitou čekajících, až se uvolní jeho místo. Vzhledem k jistotě svého zaměstnání měli tito čekatelé menší motivaci podávat maximální výkon než jejich kolegyně a kolegové na mimouniverzitních institucích. Tomu odpovídá skutečnost, že podle Fleckových údajů byli soukromí docenti z mimouniverzitních ústavů úspěšnější v získávání profesur v Rakousku nebo v zahraničí než interní 
docenti [s. 66]. Systém profesorských stolic silně podporoval personální uzavřenost a celoživotní kariéry v mocenském okruhu jednoho profesora. Problematičnost takového uspořádání je zjevná. Zkušenosti z českého prostředí však ukazují, že inbreedingu se daří i v systému organizovaném na principu kateder.

V souvislosti s univerzitami je na místě vsuvka týkající se habilitace, jedné z klíčových institucí stř̌edoevropských vysokoškolských systémů. Fleck jí nikoli náhodou věnuje celou jednu kapitolu patřící $\mathrm{k}$ nejvíce kritickým z celé knihy. Procedura, která vychází ze stejného historického základu a začala se pomalu odlišovat až po roce 1918, je v Rakousku i České republice stále dost podobná a trpí podobnými nedostatky. Fleck připomíná, že ještě počátkem osmdesátých let se uchazeči, kteří nebyli favority vlivných profesorů, nebo např́klad ženy a levicoví kandidáti běžně na rakouských univerzitách setkávali s obstrukcemi a mnozí z nich byli donuceni opustit akademickou dráhu nebo odejít do zahraničí [s. 58]. Základními rysy rakouského habilitačního řízení jsou podle něj: tajnost a uzavřenost klíčových momentů jednání, rozhodující role předsedy habilitační komise, rozehrávání mocenských her mezi vlivnými profesory, očekávání poslušnosti od uchazeče. Shrnuto: „Přinejmenším v sociologii habilitace nikdy nefungovala jako neosobní a platný měřicí nástroj, nýbrž jako ponižující zkouška ve výběrovém procesu, $\mathrm{v}$ němž je upřednostňována servilita jako předpoklad nejprve pro přijetí na čekatelské místo a posléze, pokud se dotyčná osoba i nadále chová konformně, také s určitým štěstím na ceněné místo profesora." [s. 68]

Podobnosti s českou situací jsou více než zřejmé. Česká legislativa podobně jako rakouská zneužitelnou diskreci rozhodování u předsedy a ostatních členů komise a rovněž u představitelů fakulty omezuje. Přesto hrají v habilitačních řízeních Fleckem uváděné prvky, zejména snaha hlavních hráčủ o posílení své vědecko-politické pozice nebo servilita a nadměrné projevování respektu ke starším osobám u mnohých kandidátů [s. 61-62], velmi podstatnou roli. Zároveň je opět třeba říci, že Fleckova kritika je př́liš vyhrocená a zřejmě neplatí v plné síle pro novější období. Jím uváděné případy odmítnutých habilitací nakonec neskončily pro uchazečky zcela špatně. Knorr-Cetina se musela habilitovat v německém Bielefeldu a posléze byla profesorkou tamtéž a v Kostnici, v Rakousku tedy v akademické dráze nepokračovala. Ale jiná absolventka IHS Marina Fischer-Kowalski (dcera u nás $\mathrm{v}$ šedesátých letech vlivného rakouského marxistického teoretika Ernsta Fischera) nakonec po dlouhých průtazích v Rakousku habilitaci získala, a dokonce se stala profesorkou oboru sociální ekologie na univerzitě v Celovci (Klagenfurtu) [s. 58].

Kritizovaná uzavřenost a hierarchičnost rakouských univerzit byla postupnými reformami vysokého školství opakovaně oslabována, takže lze soudit, že dnes je situace v mnoha ohledech lepší než před třiceti lety. Současnou podobu univerzit v Rakousku Fleck nepopisuje. Aspoň však ukazuje, že sociální pozice profesorů během let zaznamenala výrazný úpadek. Vztaženo k ekonomické produktivitě země měli profesoři v Rakousku v roce 1930 čtyřikrát větší platy než v současnosti (dvanáctinásobek HDP na hlavu ve srovnání s trojnásobkem HDP 
na hlavu). Dlužno dodat, že i jejich dnešní platy jsou stále výrazně vyšší než platy profesorů v ČR (trojnásobek rakouského HDP na hlavu odpovídá hrubému příjmu přes 250000 Kč měsíčně) [s. 78].

\section{Mimouniverzitní ústavy: od zlaté éry v sedmdesátých letech po úpadek po roce 2000}

I když nový rozvoj rakouské sociologie započal podobně jako v Československu v šedesátých letech, vrcholu dosáhl - a zde už bohužel podobnost s československou sociologií neplatí - až v následující dekádě. V roce 1970 se na 13 let ujala vlády sociální demokracie pod vedením kancléře Bruna Kreiskyho. Jednou z jeho nejbližších spolupracovnic a po celou dobu jeho vlády ministryní nově vytvořeného rezortu vědy a výzkumu byla politička, novinářka a socioložka Hertha Firnberg. V politické rétorice i praxi se do popředí dostala sociálnědemokratická reformní agenda, k jejímuž uskutečňování bylo zapotřebí expertních znalostí a výzkumů [s. 44, 52]. Pro empirické sociology, zejména, ale zdaleka nejen z Ústavu vyšších studií, se otevřely dosud netušené možnosti. Reformní vítr zasáhl i univerzity. Jedním z kroků Kreiského vlády byla reorganizace univerzit v roce 1975 směřující $\mathrm{k}$ jejich demokratizaci.

Když počátkem šedesátých let stoupl politický význam sociální demokracie, bylo třeba uspokojit její nárok na podíl na vlivu v oblasti vědy a výzkumu. Roku 1961 tak vznikl první ústav patřící do Společnosti Ludwiga Boltzmanna, která byla kontrolována osobami spjatými $\mathrm{s}$ touto stranou. Během sociálnědemokratické hegemonie $\mathrm{v}$ sedmdesátých letech se společnost výrazně rozrostla, a to i o ústavy společenskovědního a humanitního zaměření. Akademici blízcí sociální demokracii byli při rozhodování o zakládání nových Boltzmannových ústavů a poskytování podpory preferováni. Současně smluvní financování zaručovalo trvalou závislost těchto ústavů na zřizovateli, což politikům vyhovovalo. Některé ústavy vznikly jako odměna vlivným univerzitním profesorưm za jejich souhlas s univerzitní reformou [s. 52-53]. Pro pracovníky mimouniverzitních ústavů bylo výhodou, že byly ve srovnání s univerzitami schopny rychleji a pružněji stanovovat svůj výzkumný program. Nevýhodou naopak bylo to, že oni sami byli na rozdíl od svých kolegů z univerzit pouhými zaměstnanci bez akademické autonomie [s. 74].

Boltzmannova společnost byla štědře financována ze spolkového rozpočtu. Díky ní mohla vláda poskytovat podporu novým výzkumným směrům, které by se na univerzitách obtížně prosazovaly. Avšak řada těchto často velmi malých ústavů byla řízena osobami nepatřícími ke špičkám univerzitní hierarchie, což mělo za následek, že se rakouská sociologie rozpadla na dva světy: uzavřený svět univerzitní sociologie, $v$ němž vládli postarší profesoři a výzkum se prováděl jen v omezeném rozsahu, a na druhé straně výzkumně čilý, ale zato mnohem méně stabilní svět mimouniverzitních ústavů, v němž převládali mladí a počátkem se- 
dmdesátých let ještě málo zkušení výzkumníci [s. 53-54]. Toto rozdvojení podle Flecka přetrvalo až do první dekády nynějšího století.

Sféra mimouniverzitních ústavů v Rakousku byla velmi široká. Vedle IHS a Boltzmannovy společnosti zahrnovala řadu organizací zřizovaných státem, spolkovými zeměmi nebo městy, tripartitními institucemi, Rakouskou akademií věd nebo na základě mezinárodních smluv [s. 73-74]. Je vhodné doplnit aspoň některé zástupce poslední skupiny, protože právě na nich v různých dobách působila nebo s nimi spolupracovala na projektech řada českých sociálních vědců: Evropské koordinační středisko pro výzkum a dokumentaci ve společenských vědách při UNESCO a Evropské středisko pro sociální politiku a výzkum při OSN, obě sídlící ve Vídni, nebo u badatelů o vztazích mezi Západem a Východem během studené války dobře známý Mezinárodní ústav pro aplikovanou systémovou analýzu (IIASA) v nedalekém Laxenburgu.

Rozvoj mimouniverzitních výzkumných center a s ním spojený boom empirické sociologie v sedmdesátých letech byly podle Flecka hlavním impulzem ke vzniku prvního rakouského sociologického časopisu Österreichische Zeitschrift für Soziologie v roce 1976. Časopis od počátku vydává Rakouská sociologická společnost, ale jeho redakce nesídlila - př́iznačně pro tehdejší poměry - na některé z univerzit, nýbrž na IHS [s. 55]. Přibližně o dekádu později se objevily další sociologické časopisy: SWS-Rundschau a Innovation - The European Journal of Social Science.

Zlatá éra mimouniverzitních výzkumných center provozovaných pod patronací rakouské sociální demokracie skončila během osmdesátých let, kdy se rakouská politika vrátila k modelu velkých koalic sociálních demokratů a lidovců. Souběžně s tím sociologie ztratila pozici výsadního poskytovatele odborné expertízy pro vládu a média. Za její hlavní konkurenty, kteří se objevili počátkem devadesátých let, Fleck označuje kulturální studia a komerční poradce [s. 72].

Mimouniverzitní ústavy spojovaly velké naděje se vstupem Rakouska do Evropských společenství v roce 1995 a vskutku se poměrně úspěšně podílely na vědeckých projektech $\mathrm{v}$ rámcových programech EU. I když však dosáhly na více projektů než rakouské univerzity, převážně prakticko-politické zaměření těchto evropských projektů způsobilo, že se mimouniverzitní ústavy nestaly trvalou platformou pro základní výzkum [s. 75]. Tento rakouský př́íklad potvrzuje českou zkušenost posledního desetiletí, že evropské programy nejenže nepomáhají trvalému rozvoji národních vědeckých institucí, ale mohou mu dokonce škodit.

Po roce 2000, kdy sociální demokracie ztratila zastoupení v rakouské vládě, Boltzmannova společnost prošla hlubokou reformou a téměř všechny její společenskovědní ústavy byly postupně uzavírány [s. 73]. Nová rakouská vláda po čtyřiceti letech podpory mimouniverzitních ústavů obrátila kurz a zaměřila se na rozvoj univerzitního výzkumu. S tím souvisela významná vysokoškolská reforma v roce 2004, která mezi jinými novinkami zavedla tříleté kontraktové financování univerzit [s. 76]. 


\section{Závěrem}

Fleckova kniha nabízí celou řadu př́iležitostí k zamyšlení nad tím, jak by se bývala mohla vyvíjet česká sociologie, kdyby se podmínky pro její fungování více podobaly těm rakouským. Srovnání mezi tempem vývoje obou sociologií od šedesátých let minulého století zavdává pramálo důvodů k dnes populární obhajobě československého komunistického režimu. Mezi zasahováním politických stran do chodu sociologie v Rakousku a strnulou ideologickou kontrolou v normalizačním Československu je rozdíl v řádech, a nikoli ve stupních. Osudovým zásahem do budoucnosti československé sociologie bylo její odříznutí od mezinárodních, především západních vědeckých a akademických struktur. Příklad IHS a jeho pozitivního vlivu na šance rakouských sociologů na mezinárodní uplatnění je poučný. Rakouská sociologie jistě těžila ze specifického postavení Rakouska během studené války jako místa setkávání mezi Západem a Východem a sídla mnoha mezinárodních organizací. Podstatnější však byla samotná možnost otevírat se světu, politická podpora rozvoje mezinárodně uznávaných výzkumných pracovišt' a značná organizační podnikavost některých zástupců oboru. V této oblasti nabrala česká sociologie a celá česká akademická sféra zpoždění, které se dodnes nepodařilo překonat.

Jiné možné zjištění se týká užitečnosti institucionální pestrosti pro rozvoj vědeckých oborů. Z Fleckova výkladu je patrné, že jak univerzity, tak i mimouniverzitní výzkumná centra měly svá slabá místa. Univerzity byly zkostnatělé, hierarchické a nepraktické instituce, které často prováděly jen velmi slabý výzkum. Mimouniverzitní ústavy byly úspěšnější při získávání grantů i při tvorbě výzkumných výsledků a otevřenější mladým a nekonformním badatelům, ale zároveň je omezovala silná závislost na politické patronáži. Zdá se, že rakouské univerzity se dokázaly tlaku politických stran aspoň do určité míry bránit. Akademická autonomie tedy sice může mít své dobře známé patologické následky, ale současně je něčím, čeho je ve světě stále více ovládaném politikou zapotřebí. Nezbytný je však také mimouniverzitní výzkumný sektor, který může kompenzovat nedostatky univerzit, jako je pomalé přizpưsobování se novým výzkumným trendům nebo konzervativní personální politika. Pak ale není dobrá zpráva, že o duálním systému složeném z autonomních univerzit a specializovaných mimouniverzitních ústavi̊ se v Rakousku dá čím dál tím více mluvit pouze v minulém čase, jak ukazuje pokračující rušení výzkumných institutů a pronikání manažerismu do univerzitního světa [s. 82-85]. Další vývoj může napovědět, jakým směrem se bude ubírat vysokoškolská a vědní politika i v dalších státech střední Evropy. Z tohoto i z mnoha jiných, zde většinou pouze naznačených důvodů by stálo za to rakouskou sociologii pozorně sledovat a udržovat s ní čilejší kontakty než dosud. 


\section{Literatura}

Barber, M. D. 2004. The Participating Citizen. A Biography of Alfred Schutz. Albany, NY: State University of New York Press.

Čech, V., P. Machonin. 1966. „Sociologie v Rakousku.“ Sociologický časopis 2 (6): 844-849.

Fleck, Ch. 1988. „Soziologie in Österreich nach 1945.“ Pp. 123-147 in Ch. Cobet (ed.). Einführung in Fragen an die Soziologie in Deutschland nach Hitler 1945-1950. Frankfurt am Main: Cobet.

Fleck, Ch. 1990. Rund um "Marienthal": von den Anfüngen der Soziologie in Österreich bis zu ihrer Vertreibung. Wien: Verlag für Gesellschaftskritik.

Fleck, Ch., H. Nowotny. 1993. „A Marginal Discipline in the Making: Austrian Sociology in a European Context." Pp. 99-118 in B. Nedelmann, P. Sztompka (eds.). Sociology in Europe: In Search of Identity. Berlin: de Gruyter.

Galtung, J. 1981. „Structure, Culture and Intellectual Style: An Essay Comparing Saxonic, Teutonic, Gallic and Nipponic Approaches." Social Science Information 20 (6): 817-856.

Hayek, F. A. 1992. The Fortunes of Liberalism: Essays on Austrian Economics and the Ideal of Freedom. London: Routledge.

Hoffmann, J. 1934. „K sociologii nezaměstnanosti.“ Sociologická revue 5 (1-3): 196-202.

Illner, M., P. Machonin. 1992. "První evropská sociologická konference, Vídeň 1992." Sociologický časopis 28 (6): 823-826.

Janák, D. 2014. The Institutionalisation of Sociology in Central Europe. Opava: Silesian University.

Jeřábek, H. 1993. „XIII. Rakouský sociologický kongres.“ Sociologický časopis 29 (4): $555-556$.

Jeřábek, H. 2014. Slavné sociologické výzkumy (1899-1949). Praha: Sociologické nakladatelství (SLON).

Míšková, A. 2002. Německá (Karlova) univerzita od Mnichova k 9. květnu 1945. Praha: Karolinum.

Szacki, J. 1995. „Wstęp: krótka historia socjologii polskiej.“ Pp. 11-119 in Sto lat socjologii polskiej: od Supińskiego do Szczepańskiego. Warszawa: Wydawnictwo naukowe PWN.

Večerník, J. 1993. „Založení Nadace START pro výzkum sociální transformace." Sociologický časopis 29 (2): 272-274. 